\title{
Epidemiology of babies dying at different ages from the sudden infant death syndrome
}

\author{
JONATHAN P NICHOLL AND ALICIA O'CATHAIN \\ From the Medical Care Research Unit, Department of Community Medicine, University of Sheffield Medical \\ School, Sheffield.
}

ABSTRACT An analysis of data from the United Kingdom multicentre study of postneonatal mortality has been made to assess whether there are causally distinct groups of babies dying from the Sudden Infant Death Syndrome (SIDS), and to develop explicit risk factor profiles for the subgroups.

The 303 SIDS babies in the multicentre study were divided into four subgroups by age at death: weeks $1-7,8-15,16-23$, and 24 or more weeks. Contrasts between these subgroups with respect to 28 epidemiological characteristics and to pathology findings were investigated. Significant contrasts in the number of previous pregnancies, duration of the 2nd stage of labour, gestational length, family finances and repair of housing were found. Overall, very strong evidence of epidemiological differences was found $\left(\chi_{9}^{2}=29.3, p<0.001\right)$, and of contrasts in the nature and degree of any acquired terminal disease.

It is concluded that there are different causes of SIDS with different distributions according to age at death.

The majority of sudden unexpected infant deaths (cot deaths) are also unexplained at necropsy, ${ }^{1}$ and such unexplained cot deaths (Sudden Infant Death Syndrome, SIDS, deaths) made up about $35 \%$ of all postperinatal deaths in the UK in $1985 .^{2}$ In 1986 there was an unusual increase in the infant death rate specific to the postneonatal period ${ }^{3}$ which was partially accounted for by a $15 \%$ increase in the number of recorded SIDS deaths. ${ }^{4}$

It is now widely believed that SIDS may not be a single entity, and that a number of different mechanisms can lead to SIDS deaths. If this is true then there are important implications for developing strategies for prevention. Since the causes of SIDS deaths are, by definition, not known, the usual route for prevention is not open, at least in the short term. The options, then, are either to identify infants in high risk groups and to intervene in the health care of individual babies during the early months of their lives ${ }^{5}$ or to adopt a broader population approach by trying to lower the incidence of risk factors. ${ }^{6}$ The advantages of small reductions in risk throughout the whole population have been described in relation to other causes of mortality. ${ }^{7}$ Both strategies require identification of risk factors for SIDS. However, if SIDS is a syndrome with not one but several causes, then considering all SIDS cases together may have confused the epidemiology and blurred the identification of the risk factors. Some factors important in the deaths of one group of babies may have been missed through pooling all the subgroups.

Since appropriate subgroups cannot be identified by their actual underlying causes, it is necessary to use some proxy variable(s) which are most likely to differ between any causal groups. The most obvious candidates for such proxy measures are age at death and the necropsy findings.

With respect to age at death, it is prima facie reasonable to suppose that if there are different causes of SIDS then they will have distinct, though probably overlapping, age at death distributions. So subdividing the babies into different age at death groups will result in subgroups with different mixtures of causes of death and different epidemiological profiles. Indeed, whether or not age at death subgroups have distinct epidemiology might be used to assess the multiple cause hypothesis.

On the other hand, the question of whether or not pathologically distinct subgroups of SIDS would have different mixtures of causes of death is complicated by lack of knowledge about the pathology of live babies who survive infancy.

Accordingly, we have investigated the epidemiological evidence for the multiple cause hypothesis with respect to age at death, and developed explicit epidemiological, or risk factor, profiles for each of the subgroups. 


\section{Methods}

The data on 988 babies who died at between 1 week and 2 years old and 773 controls matched for date and place of birth which were collected for the UK Multicentre Study of Post Neonatal Mortality ${ }^{8}$ have been further analysed in this study. The data and methods have been thoroughly described previously. Eight centres were included in the study, which ran between 1976 and 1979, and data were obtained on each death from hospital records, home interviews, general practitioner and health visitor records, and necropsy findings.

Excluding babies who did not have a thorough necropsy, there were 303 babies in the study $(31 \%$ of the total) whose deaths were not explained or expected, and which would usually be labelled "SIDS" in accordance with the definition of Beckwith. ${ }^{9}$ These are the subject of this enquiry. Nearly half $(42 \%)$ of these babies were completely symptomless before death, a fifth $(21 \%)$ had non-specific symptoms and the remainder had symptoms of specific illnesses (typically of upper respiratory tract infections) not sufficient to explain the deaths.

In these 303 cases the relevance of the pathology findings to the death under the headings "terminal disease", "metabolic disturbance" and "tissue damage" has further been assessed as "major", "minor", or "none" (see the Multicentre Study report, appendix 1). The last group includes a few babies in whom pathology, though present, was not assessed as having any bearing on the deaths.

Infants with acquired terminal disease were also grouped by the anatomical system in which the disease was recognised. The main sites being the upper and lower airways (URT, LRT respectively,) the gastrointestinal system (GI), and "other" sites.

For the purposes of comparing the epidemiology of older and younger SIDS deaths, the age at death distribution has often been dichotomised at 12 weeks, and in order that our results should be directly comparable with these studies we also dichotomised the age distribution at 12 weeks. However, most population studies show little evidence of a bimodal distribution in age at death, ${ }^{10}$ and we did not observe two peaks in the distribution on either side of 12 weeks in the multicentre data either (see fig 1). Accordingly, for the main analysis, the age distribution was first divided at the median (15 weeks), and then the lower age group was subdivided into two intervals of equal length (less than 8 weeks, and 8 to 15 weeks), and the upper interval divided to give a third interval of the same length (16 to 23 weeks). The remainder of the deaths comprise one group of older deaths. The use of four intervals chosen in this way avoided any selection

biases and enabled any trends in the associated epidemiology to be identified.

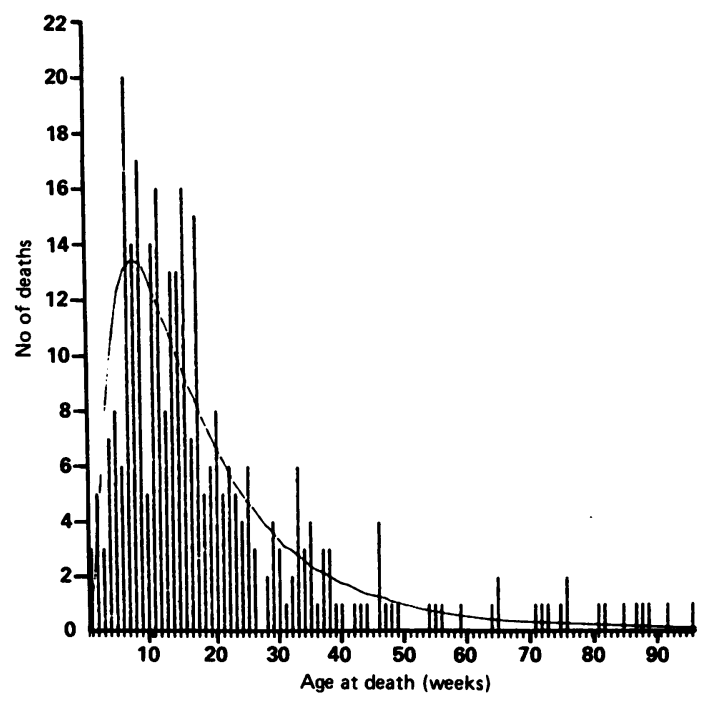

Fig 1 Observed and estimated age at death distribution. The smooth curve gives the relative frequency with which deaths occur at different ages estimated by a log-normal distribution curve fitted by equating moments.

The Multicentre Study collected information on an extensive range of characteristics of the infant, the mother, the pregnancy and the infant's social and familial environment. Twenty eight characteristics which are widely thought to be risk factors for SIDS or which have recently been discussed in the literature as possible factors in SIDS, and for which there was at least weak evidence $(p<0.1)$ that the cases and controls differed, were included in the analysis (see table 1).

Table 1 Characteristics included in the analysis

$\begin{array}{rlll}1 & \text { Birthweight } & 15 & \begin{array}{l}\text { Duration of 2nd stage of labour } \\ 2\end{array} \\ 3 & \text { Length of gestation } & 16 & \begin{array}{l}\text { Number of antenatal } \\ \text { consultations }\end{array} \\ 4 & \begin{array}{l}\text { Attendance at a special care } \\ \text { baby unit (SCBU) }\end{array} & 17 & \begin{array}{l}\text { Time of first antenatal } \\ \text { consultation }\end{array} \\ 5 & \text { Time in SCBU } & 18 & \text { Weeks delay in seeing GP } \\ 6 & \text { Singleton/multiple birth } & 19 & \text { Time of first hospital contact } \\ 7 & \text { Number of home contacts with } & 20 & \text { Ownership of accommodation } \\ & \text { GP } & 21 & \text { Type of accommodation } \\ 8 & \text { Number of contacts with GP } & 22 & \text { State of repair of } \\ \text { before death } & 23 & \text { Cleanmodation } \\ 9 & \text { Sex } & 24 & \text { Financial circumstances } \\ 10 & \text { Mother's age at delivery } & 25 & \text { Social class of father } \\ 11 & \text { Mother's smoking habits } & 26 & \text { Family problems } \\ 12 & \text { Number of previous pregnancies } \\ 13 & \text { Interval between births } & 27 & \text { Employment status of father } \\ 14 & \text { Other infant deaths } & 28 & \begin{array}{l}\text { Ratio of people to rooms in } \\ \text { home }\end{array} \\ & & & \end{array}$

1 Birthweight

3 Feeding

4 Attendance at a special care

before death

11 Mother's smoking habits

Number of previous pregnancies

13 Interval between birth 
The question of whether the distribution of each of the epidemiological characteristics differed between the age at death subgroups was investigated by comparing the distributions using $\chi^{2}$ tests (after categorising those characteristics measured on continuous scales), and a multivariate discriminant analysis was carried out to assess the evidence as a whole for whether there are differences in the epidemiology of babies dying at different ages (with the categorical variables dichotomised and treated as continuous).

Multiple logistic regression models have also been fitted separately to each subgroup of cases and controls to identify a group of factors which taken jointly appear to discriminate most sharply between the cases and controls. The resulting models identify a small group of factors which, taken together, are associated with an increased risk of a SIDS death within that subgroup.

\section{Results}

The numbers of cases and pathology profiles of each of the four age at death subgroups are shown in table 2.

Table 2 Pathology profiles of age at death subgroups

\begin{tabular}{|c|c|c|c|c|}
\hline \multirow[b]{2}{*}{ Pathology findings } & \multicolumn{4}{|c|}{ Age at death, weeks (\%) } \\
\hline & $1-7$ & $8-15$ & $16-23$ & $24-103$ \\
\hline \multicolumn{5}{|c|}{ Acquired terminal disease: } \\
\hline None & $34 \cdot 6$ & $24 \cdot 0$ & $14 \cdot 7$ & $9 \cdot 6$ \\
\hline $\begin{array}{l}\text { Minor } \\
\text { URT } \\
\text { LRT } \\
\text { GI } \\
\text { Other }\end{array}$ & $\begin{array}{r}38.5 \\
5.8 \\
1.9 \\
1.9\end{array}$ & $\begin{array}{r}32.0 \\
14.0 \\
2.0 \\
0.0\end{array}$ & $\begin{array}{r}36.8 \\
16.2 \\
5.9 \\
0.0\end{array}$ & $\begin{array}{r}21 \cdot 7 \\
15 \cdot 7 \\
6 \cdot 0 \\
2 \cdot 4\end{array}$ \\
\hline All & $48 \cdot 1$ & $48 \cdot 0$ & $58 \cdot 8$ & $45 \cdot 8$ \\
\hline $\begin{array}{l}\text { Major } \\
\text { URT } \\
\text { LRT } \\
\text { GI } \\
\text { Other }\end{array}$ & $\begin{array}{l}5.8 \\
7.7 \\
1.9 \\
1.9\end{array}$ & $\begin{array}{r}7.0 \\
11.0 \\
7.0 \\
3.0\end{array}$ & $\begin{array}{r}7.4 \\
11.8 \\
5.9 \\
1.4\end{array}$ & $\begin{array}{r}8.4 \\
22.9 \\
9.6 \\
3.7\end{array}$ \\
\hline All & $17 \cdot 3$ & $28 \cdot 0$ & $26 \cdot 5$ & $44 \cdot 6$ \\
\hline \multicolumn{5}{|c|}{ Metabolic disturbance: } \\
\hline None/Minor & $59 \cdot 6$ & $64 \cdot 0$ & $72 \cdot 1$ & $59 \cdot 0$ \\
\hline Major & 40.4 & 36.0 & $27 \cdot 9$ & $40 \cdot 0$ \\
\hline \multicolumn{5}{|l|}{ Tissue damage: } \\
\hline None & $25 \cdot 0$ & $26 \cdot 0$ & $26 \cdot 5$ & $19 \cdot 3$ \\
\hline Minor & $61 \cdot 5$ & 67.0 & $66 \cdot 2$ & $60 \cdot 2$ \\
\hline Major & 13.5 & 7.0 & $7 \cdot 4$ & $20 \cdot 5$ \\
\hline All cases $\mathrm{n}=100 \%$ & 52 & 100 & 68 & 83 \\
\hline
\end{tabular}

There is a striking contrast between the pathology profiles of the subgroups. Whilst $35 \%$ of babies dying between 1 and 7 weeks old had no acquired disease and $39 \%$ had only minor URT infections at the time of death, only $10 \%$ of babies dying at over 24 weeks had no evidence of disease and only $22 \%$ had minor URT infections. Babies dying at intermediate ages had intermediate levels of disease.

Five characteristics (number of previous pregnancies, duration of the 2nd stage of labour, gestational length, family finances, and repair of housing) discriminated significantly between the four age at death groups of SIDS deaths. Some weak evidence was also found that family problems discriminated between the subgroups. When these variables were entered into a multivariate discriminant analysis, the number of previous pregnancies, family finances, and the state of repair of the family's housing were found to discriminate independently between the subgroups. Overall, very strong evidence was found that these three characteristics, taken jointly, discriminated between babies dying at different ages $\left(\chi_{9}^{2}=29.3, p<0.001\right)$.

Given, then, that the subgroups are epidemiologically distinct, a risk profile was drawn up for each group separately. The only characteristic found to be (significantly) associated with increased risk in all four groups was birthweight. The risk associated with multigravidity and young mothers increased with age (see figs 2 and 3) and a similar effect
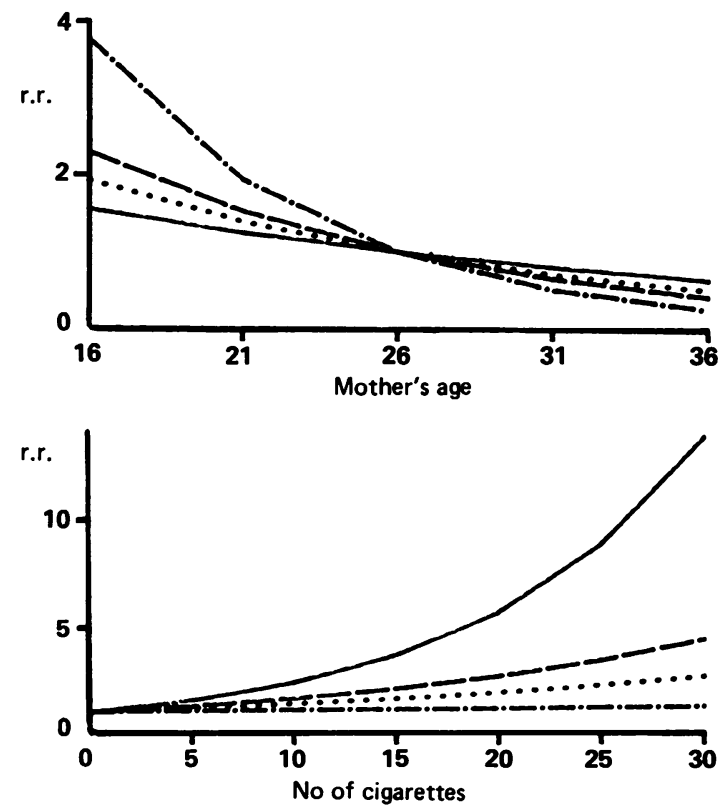

Fig 2 Estimated relative risk of death by mother's age and number of cigarettes smoked per day during pregnancy. Risks are estimated relative to infants of mothers aged 26 and non-smokers in four age groups.

1-7 weeks, ……8-15 weeks, - - - 16-23 weeks, - - - over 24 weeks. 
was seen with regard to the state of housing of the infant (fig 3). In contrast, the risks associated with mothers smoking during pregnancy and attendance at a special care baby unit (figs 2 and 3 ) show the

$\begin{array}{ccccc}\begin{array}{c}\text { Age at death } \\ \text { (weeks) }\end{array} & 1.7 & 8-15 & 16-23 & 24+\end{array}$
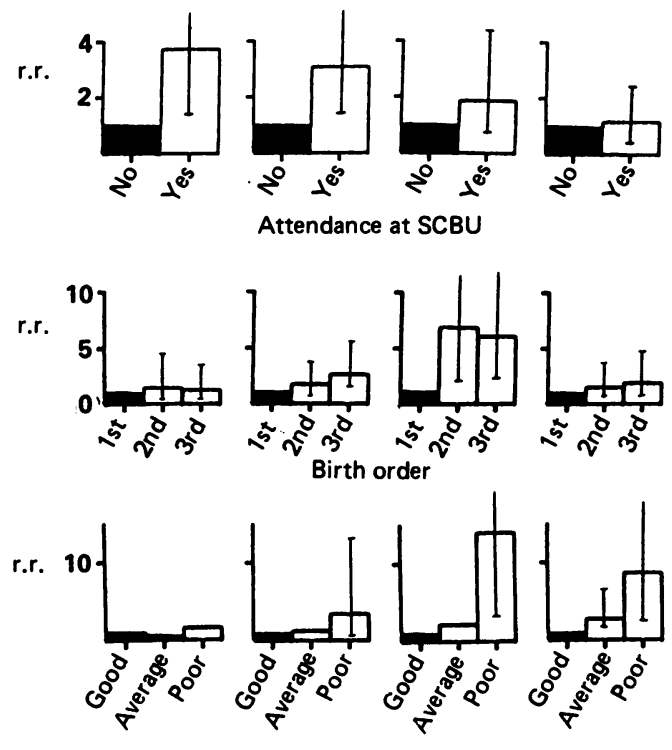

State of repair of housing

Fig 3 Estimated relative risk of death by number of previous pregnancies, house repair and attendance at a special care baby unit $\left(S C B C^{\prime}\right)$. Relative risks are estimated from odds ratios relative to infants of primigravid mothers, in housing of good repair, who did not attend an SCBU. Vertical lines give approximate $95 \%$ confidence intervals.

opposite effect, the risk decreasing at increasing ages. When all the characteristics were entered into the logistic regression models, the resulting risk profile for young babies included only mother's smoking during pregnancy as a significant risk factor (see table 3 ) for which the risk of death was found to increase threefold for every 10 cigarettes smoked per day. In the older age groups the profiles are not dissimilar from each other. They all include birthweight or gestational age and some indicator of possible socio-economic deprivation (family problems in peak age infant deaths, repair of housing in the post-peak age group, and family finance in the oldest group). The number of previous pregnancies considerably increased the risk in both the middle age groups but was not included in the risk profile of the oldest group of infants.

Comparing the two age groups 1-11 weeks and $12+$ weeks, six characteristics (number of previous pregnancies, financial problems, gestational age and three aspects of housing) discriminated significantly between infants who died at the younger ages $(n=102)$ and the others $(n=201)$. When multivariate profiles were drawn up separately for the two groups, multigravidity and a poor state of repair of housing were found to be associated with a substantially increased risk only in the older babies (see table 4), whilst maternal smoking during pregnancy was only a significant risk factor in the profile of babies under 12 weeks of age.

\section{Discussion}

EVIDENCE FOR SEVERAL CAUSES

Some previous authors have commented on differences between older and younger babies following the observations of Kraus et al, ${ }^{11}$ who noticed that SIDS was associated with weather factors only in older babies, and Fedrick ${ }^{12}$ who found that, relative to younger groups, older SIDS deaths commonly occurred in winter in male babies. Neither of these factors was found to be significantly more pronounced in the multicentre study in SIDS deaths occurring after 12 weeks. Fedrick, ${ }^{13}$ however, also

Table 3 Risk profiles

\begin{tabular}{|c|c|c|c|c|c|}
\hline \multirow{2}{*}{$\begin{array}{l}\text { Age at death } \\
1-7 \text { weeks } \\
n=52\end{array}$} & \multicolumn{5}{|c|}{ Characteristics with significant relative risks. ${ }^{*}$ Values are relative risk ( $95 \%$ confidence interval) } \\
\hline & \multicolumn{5}{|c|}{$\begin{array}{l}\text { Number of cigarettes smoked by mother during pregnancy } \\
1.81(1.25,2 \cdot 62)\end{array}$} \\
\hline $\begin{array}{l}8-15 \text { weeks } \\
n=100\end{array}$ & $\begin{array}{l}\text { Family problems } \\
5 \cdot 59(2 \cdot 16,14 \cdot 51)\end{array}$ & + & $\begin{array}{l}\text { birthweight } \\
1 \cdot 57(1 \cdot 15,2 \cdot 16)\end{array}$ & + & $\begin{array}{l}\text { at least one previous pregnancy } \\
2.76(1.37,5 \cdot 55)\end{array}$ \\
\hline $\begin{array}{l}16-23 \text { weeks } \\
n=68\end{array}$ & $\begin{array}{l}\text { At least one } \\
\text { previous pregnancy } \\
7.53(2.38,23.83)\end{array}$ & $\begin{array}{l}\text { housing ir } \\
13.37(1.8\end{array}$ & $\begin{array}{l}\text { poor repair } \\
1,98 \cdot 71)\end{array}$ & $\begin{array}{l}\text { birthweight } \\
1 \cdot 72(1.81,2 \cdot 08)\end{array}$ & $\begin{array}{l}+\quad \text { other infant death } \\
4 \cdot 11(1 \cdot 48,11 \cdot 38)\end{array}$ \\
\hline $\begin{array}{l}24+\text { weeks } \\
n=83\end{array}$ & $\begin{array}{l}\text { Inadequate family finance } \\
3.92(1 \cdot 62,9 \cdot 50)\end{array}$ & + & $\begin{array}{l}\text { length of gestation } \\
1.43(1 \cdot 15,1 \cdot 78)\end{array}$ & + & $\begin{array}{l}\text { mother's age } \\
1.65(1 \cdot 11,2 \cdot 44)\end{array}$ \\
\hline
\end{tabular}

The increase in risk for smoking is given for an increase of 5 cigarettes smoked per day, for birthweight for a decrease of $500 \mathrm{~g}$, for gestational period for 1 week less, and for mother's age for 5 years younger. 
Table 4 Risk profiles

\begin{tabular}{|c|c|c|c|c|c|}
\hline \multirow{2}{*}{$\frac{\text { Age at death }}{1-11 \text { weeks }}$} & \multicolumn{5}{|c|}{ Characteristics with significant relative risks.* Values are relative risk (95\% confidence interval) } \\
\hline & $\begin{array}{l}\text { Number of cigarettes smoked by } \\
\text { mother during pregnancy } \\
1.30(1.07,1.59)\end{array}$ & + & $\begin{array}{l}\text { birthweight } \\
1.44(1.03,2.02)\end{array}$ & \multirow[t]{2}{*}{+} & \multirow[t]{2}{*}{$\begin{array}{l}\text { family problems } \\
3.09(1 \cdot 18,8 \cdot 08)\end{array}$} \\
\hline & $+\quad \begin{array}{c}\text { attendance at SCBU } \\
2.50(1 \cdot 14,5 \cdot 50)\end{array}$ & + & $\begin{array}{l}\text { smoking } \times \text { SCBU } \\
2.39(1.02,5 \cdot 60)\end{array}$ & & \\
\hline \multirow[t]{2}{*}{$\begin{array}{l}12+\text { weeks } \\
n=201\end{array}$} & $\begin{array}{l}\text { Housing in poor repair } \\
6.99(2.62,18.63)\end{array}$ & + & $\begin{array}{l}\text { length of gestation } \\
1.32(1.15,1.52)\end{array}$ & + & $\begin{array}{l}\text { mother's age } \\
1.93(1.47,2.53)\end{array}$ \\
\hline & $\begin{array}{l}+\quad \text { at least one previous } \\
\text { pregnancy } \\
4.25(2.37,7 \cdot 63)\end{array}$ & + & $\begin{array}{l}\text { family problems } \\
2 \cdot 61(1 \cdot 33,5 \cdot 14)\end{array}$ & + & $\begin{array}{l}\text { first contact with } \\
\text { hospital } \\
1.42(1.04,2.04)\end{array}$ \\
\hline
\end{tabular}

SCBU $=$ special care baby unit.

- The increase in risk for smoking is given for an increase of 5 cigarettes smoked per day, for birthweight for a decrease of $500 \mathrm{~g}$, for gestational period for 1 week less, for mother's age for 5 years younger and for first contact with hospital for 10 weeks later.

noted that low maternal age, high parity and low social class were features only of older babies, just as we have observed. The theme of respiratory infections or a winter preponderance playing a comparatively major role only in older deaths is common to many studies which have contrasted age groups, ${ }^{14-18}$ although some other studies have not found these effects. ${ }^{19-21}$

One possible reason for the difference between the findings of various studies is that they have not always used the same age groups. Beal ${ }^{22}$ used 0-8, 8-16 and 16-24 weeks, Macarthur and Bartholomew ${ }^{21}$ used 4-19 and 20-52 weeks, Kraus et al used 1-4 and 5-11 months, Carpenter and Gardner, ${ }^{15}$ and Goldberg et al $^{19}$ used monthly divisions. Others have used Fedrick's original division at 12 weeks or variations of it such as 3 months or 13 weeks. ${ }^{14} 16182023-28$ It would be appropriate to divide the babies at 12 weeks if the age at death distribution was bimodal with peaks either side of 12 weeks, as has sometimes been found. ${ }^{10}$ However, a bimodal distribution is not usually found. Indeed, commonly, 12 weeks is the unique modal age at death and a division at this age may thus be entirely inappropriate. The advantage of using several age groups is that it has been possible to identify the obvious patterns and trends in the epidemiology associated with death at different ages seen in figs 2 and 3. On the other hand, using just two larger subgroups, some factors with small associated risks have been revealed as significant.

On balance, the evidence for epidemiological contrasts at different ages available both from the patterns revealed using several age groups and the significance of the differences between the two subgroups is similar. Both analyses show strong contrasts between the risk factors for SIDS at different ages. If we were to suppose that there was a single common underlying cause of SIDS then it would be necessary to explain why this cause is only associated with certain characteristics, such as multigravidity, in some groups of babies. Plainly the contrasts in the epidemiology of SIDS at different ages are most easily explained by supposing that there are different causes or mixtures of causes of SIDS operating at different ages.

The contrast in the epidemiology of older and younger SIDS is to be found not just in what factors are significant but in the type of factor. Factors such as low birthweight, maternal smoking during pregnancy, and attendance at a special care baby unit are associated with, or indicate, a vulnerability at birth, and it is perhaps not surprising that they are associated with the deaths of very young babies. On the other hand in the older babies factors associated with the likelihood of infections - dirty housing in poor repair, and the possible presence of other children in the house-were found to be associated with the risk of SIDS. Whether as a cause or an effect, the associations are clearly reflected in the contrasting pathology of infants dying at different ages. Young SIDS infants have little pathology at the time of death compared to older SIDS infants, many of whom had LRT and GI infections. Overall, the conclusion that there are a number of different underlying causes of SIDS, with different age at death distributions, seems certain.

IMPLICATIONS FOR THE AETIOLOGY OF SIDS

With regard to younger SIDS infants, the epidemiological characteristics present few clues to the cause(s) of death. The strong association with maternal smoking during pregnancy presumably would be allied with smoking after pregnancy and around the time of the infant's death. It is known that smoking leads to an increased incidence of LRT infections ${ }^{29-31}$ but since comparatively few young babies were found to have any necropsy evidence of lower respiratory disease, it may be antenatal smoking which is the risk factor in young infants. Indeed, when 
antenatal smoking was taken into account, other indicators of neonatal vulnerability-low birthweight and time spent in a special care baby unit-no longer contributed to identifying very young babies at risk.

In infants aged between 8 and 24 weeks and in babies with some evidence of terminal disease, we typically found poor housing and multigravid mothers to be associated with the risk of SIDS. Both of these factors are likely to be associated with an increased incidence of infections and other disease in babies. Poor housing and "another" child might also be indicative of many other things, including neglect. However, other well known characteristics, such as the winter excess of SIDS, are also indicative of an infectious aetiology, at least in some SIDS cases.

\section{IMPLICATIONS FOR THE PREVENTION OF SIDS}

One possible strategy for the prevention of SIDS relies on identifying babies at risk, and in this context it has been widely reported that risk scores for SIDS as a whole often fail to identify some subgroups of SIDS. ${ }^{32}$ A discriminant analysis for all the 303 SIDS cases in this study taken together yielded eight independently significant risk factors. Among infants less than eight weeks old the positive predictive value of the discriminant function (that is, the proportion of predicted cases that were actually deaths) was $72 \%$ compared to $81 \%$ in babies aged 16-24 weeks. In contrast, a discriminant based on the single characteristic "smoking during pregnancy", identified from the multivariate profiles as a risk factor in young infants, had a positive predictive value of $79 \%$ in that group.

However, overall little improvement in the sensitivity and positive predictive values of the discriminant could be achieved by using separate subgroups functions.

The viability of the alternative approach to preventing SIDS by reducing the incidence of risk factors in the population, for example by reducing the prevalence of smoking during pregnancy, depends on the relation that the risk factors have to SIDS. Although it is neither a necessary nor a sufficient condition that the risk factor actually be a "cause" of SIDS, this would certainly make population intervention more likely to succeed. Of the few attempts to identify what qualities associations must have for them to be labelled causes, Bradford Hill's ${ }^{33}$ is the most well known. It is important, therefore, to assess the qualities of strength, consistency and so on that the epidemiological associations have. On these grounds, smoking both during and after pregnancy, and high parity might well be justifiably labelled as causes of SIDS, at least until Bradford Hill's last criterion of experimental evidence, in the form of the results of a population intervention study, could be assessed.
We are very grateful for the advice and assistance of Drs Jean Keeling and Mike Murphy and also of Professors Brian Williams and John Knowelden. We are also grateful to Lynne Schofield and Janet Morrison for their help.

This secondary analysis of the multicentre data has been supported by the Foundation for the Study of Infant Deaths. The original study and analysis was supported by the DHSS, who, together with Trent Regional Health Authority, maintain the Medical Care Research Unit. We are grateful for their support.

Correspondence to: J P Nicholl, Medical Care Research Unit, Department of Community Medicine, University of Sheffield Medical School, Beech Hill Rd, Sheffield S10 2RX.

\section{References}

${ }^{1}$ Arneil GC, Brooke H, Gibson AAM, Horvie A, McIntosh H, Patrick WSA. National post-perinatal infant mortality and cot death study, Scotland 1981-82. Lancet 1985; i: 740-3.

2 Mortality statistics, childhood. Series DH3 No. 19 . London: HMSO, 1985.

${ }^{3}$ Infant and perinatal mortality 1986: DHAs. OPCS monitor DHS3 87/4. 15th December 1987. London: Government Statistical Service.

${ }^{4}$ Sudden infant deaths 1985-87. OPCS monitor DH3 88/3. 20 December 1988. London: Government Statistical Service.

${ }^{5}$ Carpenter RG, Gardner A, Jepson M, Taylor EM, et al. The prevention of unexpected infant death. Lancet 1983; i: 723-7.

${ }^{6}$ Golding $J$. Is the sudden infant death syndrome preventable? J R Soc Med 1981; 81: 65-6.

${ }^{7}$ Rose G. Strategy for prevention: lessons from cardiovascular disease. Br Med J 1981; 282: 1847-51.

${ }^{8}$ Knowelden J, Keeling J, Nicholl JP. A multicentre study of post neonatal mortality. London: HMSO, 1985.

9 Beckwith JB. Observations on the pathological anatomy of the sudden infant death syndrome. In: Bergman AB, Beckwith JB, Ray CG, eds. Sudden Infant Death Syndrome (Proceedings of the 2nd International Conference on Causes of Sudden Death in Infants). Seattle: University of Washington Press, 1970: 83.

${ }^{10}$ Golding J, Limerick S, McFarlane A. Sudden infant death. Patterns puzzles and problems. Taunton: Open Books, 1985

${ }^{11}$ Kraus AS, Steele R, Langworth JT. Sudden unexpected death in infancy in Ontario part II: findings regarding season, clustering of deaths on specific days, and weather. Can J Public Health 1967; 58: 364-71.

${ }^{12}$ Fedrick $\mathrm{J}$. Sudden unexpected death in infants in the Oxford Record Linkage Area. An analysis with respect to time and place. Br J Prev Soc Med 1973; 27: 217-24.

${ }^{13}$ Fedrick J. Sudden unexpected death in infants in the Oxford Record Linkage Area: the mother. Br J Prev Soc Med 1974; 28: 93-7.

${ }^{14}$ Deacon EL. O'Reilly MJJ, Williams AL. Some statistical and climatological aspects of the incidence of the sudden infant death syndrome. Aust Paediatr J 1982; 15: 248-54.

${ }^{15}$ Carpenter RG, Gardner A. Variations in unexpected infant death rates relating to age, sex and season. Studies in sudden infant deaths. Studies on medical and population subjects no 45. London: HMSO, 1982. 
${ }^{16}$ Williams AL, Uren EC, Bretherton L. Respiratory viruses and sudden infant death. Br Med J 1984; 288: 1491-3.

17 Beal SM. Sudden infant death syndrome: epidemiological comparisons between South Australia and communities with a different incidence. Aust Paediatr J 1986; 22 (suppl 1): 13-6.

18 Newman NM (1986). Sudden Infant Death Syndrome in Tasmania, 1975-81. Aust Paediatr J 1986; 22 (suppl 1): 17-9.

${ }^{19}$ Goldberg J, Hornung R, Yamashita T, Wehrmacher W. Age at death and risk factors in sudden infant death syndrome. Aust Paediatr J 1986; 22 (suppl 1): 21-8.

${ }^{20}$ Cameron MH, Williams AL. Development and testing of scoring systems for predicting infants with high-risk of sudden infant death syndrome in Melbourne. Aust Paediatr J 1986; 22 (suppl 1): 37-45.

${ }^{21}$ Macarthur BA, Bartholomew SEM. A study of the sudden infant death syndrome by age. Child Care Health Dev 1987; 13: 197-206.

22 Beal SM. Epidemiological factors about SIDS in South Australia. In: Sudden Infant Death Syndrome. New York: Academic Press, 1983: 15-28.

${ }^{23}$ Franciosi RA. Respiratory infection as a trigger for sudden infant death syndrome. Minn Med 1985; 68: 271-2.

${ }^{24}$ Murphy MFG, Campbell MJ, Jones DR. Increased risk of sudden infant death syndrome in older infants at weekends. Br Med J 1986; 293: 264-5.

${ }^{25}$ Uren EC, Williams AL, Jack I, Rees JW. Association of respiratory virus infections with sudden infant death syndrome. Med J Aust 1980; 1: 417-9.
${ }^{26}$ Zink P, Drescher J, Verhagen W, Flik J, Milbradt $\mathbf{H}$. Serological evidence of recent influenza virus $A$ (H3N2) infections in forensic cases of sudden infant death syndrome (SIDS). Arch Virol 1987; 93: 223-32.

27 Watson E, Gardner A, Carpenter RG. An epidemiological and sociological study of unexpected deaths in infancy in nine areas of southern England: II symptoms and patterns of care. Med Sci Law 1981; 21: 89-98.

${ }^{28}$ Mason JK, Harkness RA, Elton RA, Bartholomew S. Cot deaths in Edinburgh: infant feeding and socioeconomic factors. J Epidemiol Community Health 1980; 32: 35-41.

${ }^{29}$ Ferguson DM, Horwood LJ, Shannon FT. Parental smoking and respiratory illness in infancy. Arch Dis Child 1980; 55: 358-61.

30 Colley JRT, Holland WW, Corkhill RT. The influence of passive smoking and parental phlegm on pneumonia and bronchitis in early childhood. Lancet 1974; ii: 1031-4.

31 Yue Chen, Wanxian $\mathrm{Li}$, Shunzhang Yu. Influence of passive smoking on admissions for respiratory illness in early childhood. Br Med J 1986; 293: 303-6.

32 Taylor EM, Emery JL, Carpenter RG. Identification of children at risk of unexpected death. Lancet 1983; ii: 1033-4.

${ }^{33}$ Bradford Hill AB. The environment and disease: Association or Causation? Proc $R$ Soc Med (Section of Occupational Medicine) 1965 January 14: 295-300.

Accepted for publication December 1988 